\title{
A SYSTEMATIC REVIEW ON SELF-REPORTED QUESTIONNAIRES TO ASSESS MEDICATION ADHERENCE IN DIABETIC PATIENTS
}

\author{
Much Ilham Novalisa Aji Wibowo ${ }^{1,2}$, Nanang Munif Yasin*3, Susi Ari Kristina ${ }^{4}$ and Yayi Suryo Prabandari ${ }^{5}$ \\ ${ }^{1}$ Doctoral Program in Pharmaceutical Science, Faculty of Pharmacy, Universitas Gadjah Mada, Yogyakarta, Indonesia \\ 2Department of Pharmacy, Faculty of Pharmacy, Universitas Muhammadiyah Purwokerto, Purwokerto, Indonesia \\ ${ }^{3}$ Department of Pharmacology and Clinical Pharmacy, Faculty of Pharmacy, Universitas Gadjah Mada, Yogyakarta, \\ Indonesia \\ ${ }^{4}$ Department of Pharmaceutics, Faculty of Pharmacy, Universitas Gadjah Mada, Yogyakarta, Indonesia \\ ${ }^{5}$ Department of Public Health, Faculty of Medicine, Public Health, and Nursing, Universitas Gadjah Mada, Yogyakarta, \\ Indonesia
}

\section{Corresponding author: Nanang Munif Yasin}

Email: nanangy@yahoo.com

\begin{abstract}
Adherence to pharmacological therapies are keys to effective treatments in diabetic patients. Previous reviews found that most adherence measurement studies on chronic diseases used a self-reported scale. However, there is no consensus on the best scale to measure adherence in diabetic patients. The purpose of this systematic review was to identify the potential self-reported scale that could be considered for measuring medication adherence in diabetic patients and to provide recommendations for researchers or clinicians to determine appropriate adherence selfreported scales in diabetic patients. This review follows general guidelines in the implementation of systematic reviews. After further review, it was found that 33 studies met all inclusion criteria from 4 databases (Wiley, Science Direct, Scopus, and PubMed). The articles were done by the PRISMA, while the keywords were determined by the PICO method. Most research was conducted in Asia (69.7\%) and America (18.2\%) on patients with type 2 diabetes (81.3\%), patients in hospitals (54.5\%), suffering for 1-6 months (54.5\%), and using a cross-sectional study design (78.8\%). HbA1C clinic data (57.6\%) were used in most studies as biological markers of adherence. The measurement scales of medication adherence in diabetic patients are MMAS-8 (57,.5\%), MMAS-4 (12.1\%), BMQ (9\%), MCQ (6\%), ARMS (3\%), ARMS-D (3\%), GMAS (3\%), LMAS-14 (3\%), and MARS-5 (3\%). This review provides information on the different self-reported scales most widely used in diabetic medication adherence research. Various aspects need to be considered before choosing the scale of adherence.
\end{abstract}

Keywords: Diabetes mellitus, medication adherence, self-report scale, MMAS-8, MMAS-4, BMQ, ARMS

\section{INTRODUCTION}

The prevalence of diabetes increases in various countries, primarily type 2 diabetes in adults'. This increase causes an increase in disease burden because of micro and macro-vascular complications disease caused by diabetes ${ }^{2}$. The combination of prevalence and high cost of diabetes treatment leads to the need for effective treatment ${ }^{1,3}$. Lifestyle modification and adherence to pharmacological therapy are critical to effective therapies and treatments in the disease ${ }^{4}$. Increasing the efficacy of adherence interventions will have a much more impact on the population of diabetic patients than increasing specific clinical treatments ${ }^{4}$.

Some review literature found variations in adherence to medication rates in diabetic patients ${ }^{5,6}$. In 2007, a review describing barriers to taking medication in diabetic patients found that this population's adherence rates ranged from $31 \%$ to $87 \%$. Subsequently, the latest review literature conducted in 2020 shows that adherence to the treatment of diabetes patients in developing countries ranged from $4 \%$ to $88 \%{ }^{5}$. Diabetes mellitus medication adherence in developed countries is relatively better than in developing countries, but this still needs to focus on health services ${ }^{5,6}$. Non-adherence medication in diabetic patients is associated with an increased risk of complications, mortality, increased use of services, health care costs, decreased quality of life, and even an increase in a country's economic burden ${ }^{2-5}$. Measuring, understanding, and knowing medication adherence will reduce this problem's negative impacts ${ }^{7}$. The assessment of medication adherence plays a pivotal role in the effectiveness of diabetic therapy. Therefore, it is necessary to find and evaluate an accurate scale for medication adherence assessment. However, medication adherence to some chronic diseases, especially diabetes, has not been identified and measured optimally ${ }^{7}$.

Several literature reviews have been conducted to summarize studies measuring medication adherence in chronic and diabetic disease ${ }^{8-10}$. The reviews found methodological problems and stated that the self-report method was more common in studies of medication adherence in the population of diabetic patients because of their ease of use in clinical settings. However, none of 
them specifically address self-reported methods in diabetics populations. The purpose of this systematic review was to summarize a selfreported scale update that could be considered for measuring medication adherence in the diabetic population and to provide recommendations for researchers or clinicians to determine appropriate adherence self-reported scales in diabetic patients.

\section{METHODS}

\section{Study identification}

Keywords and electronic database combinations are performed to get more relevant research studies through an extensive search from Wiley Online, Science Direct, Scopus, and PubMed ${ }^{11}$. The last searching process was run in July 2020. A preliminary hand search of the literature was completed to identify appropriate keywords based on PICO (population, intervention, comparison, outcome) search strategies are shown in Figure $1^{12}$. The inclusion and exclusion criteria are shown in Table 1 . Two research members screened all titles/abstracts and reviewed them to determine whether they meet the inclusion criteria or not. Papers that were not based on original research (i.e., the study was an Editorial, Case Report, Brief Report, Pilot Study, Commentary, Qualitative Study, Systematic Review, Literature Review, Guideline) were discarded.

\section{Study quality assessment}

There were 856 abstracts obtained from four databases, 45 articles fulfilling the full-text screening requirements. After further review, it was found that 33 studies met all inclusion criteria. The screening was accomplished according to the Preferred Reporting Items for Systematic Reviews and Meta-Analyses (PRISMA) method shown in Figure 2. Two reviewers independently assessed the possibility of bias using 14 items from the National Institute of Health (NIH) quality assessment tool for observational cohort and cross-sectional studies ${ }^{13}$.

\begin{abstract}
Data extraction
Data were extracted from selected papers by one reviewer and were then double-checked by another. There were no conflicts between the reviewers and authors of the articles in final selection decisions. Studies that met the following predetermined inclusion criteria were considered for data extraction and analysis. The extracted papers summarize the general characteristics of included studies compiled in Table $2 \mathrm{a}$ and $2 \mathrm{~b}$. Another extracted data summarizes the correlation between scale validation and biological markers of diabetes compiled in Table 3 . Finally, the summarizes of the self-reported scale for medication adherence in diabetic patients is compiled in Table 4.
\end{abstract}

Table 1: Criteria for inclusion and exclusion for the article reviewed

\begin{tabular}{lll}
\hline No & Inclusion Criteria & Exclusion Criteria \\
\hline 1. & $\begin{array}{l}\text { Measuring adherence to at least one type } \\
\text { of diabetes medication as a primary or } \\
\text { secondary outcome. }\end{array}$ & $\begin{array}{l}\text { The article was not based on original research (i.e., } \\
\text { the study was a Editorial, Case Report, Brief } \\
\text { Report,Pilot Study, Commentary, Qualitative study, } \\
\text { Systematic, review, literature Review, Guideline) }\end{array}$ \\
2. $\begin{array}{l}\text { Mention the details of the methods used to } \\
\text { measure the level of adherence }\end{array}$ & $\begin{array}{l}\text { Adherence to self-monitoring, diet, exercise, } \\
\text { guideline, clinical care, self-care, lifestyle }\end{array}$ \\
3. Published in the English language & \\
4. Published in the period 2009-2019 & \\
5. Accessible in full-text &
\end{tabular}

\section{RESULTS}

\section{Details of selected studies}

The summary of systematic searching is originated from various scientific journal databases. Most of the studies were conducted in Asian and American countries to type 2 diabetes patients in hospitals. Most research used HbA1c (Glycated hemoglobin) clinic data $(57.6 \%)(n=19)$ as a biological marker of adherence compared to blood sugar data and used a cross-sectional research design (78.8\%) ( $n$ $=26$ ). The majority of studies did not carry out a scale adaptation process through validation tests or adequate psychometric tests. However, ten of them conducted a scale adaptation process based on the World health organization (WHO), The Professional Society for Health Economics and
Outcomes Research (ISPOR), or Agency for Healthcare Research and Quality (AHRQ) for Translation and Cultural Adaptation guidelines ${ }^{14-}$ ${ }^{16}$. The summary of selected studies was listed in Table $2 \mathrm{a}$ and $2 \mathrm{~b}$.

\section{Methodological characteristics}

The most of selected studies were cross-sectional research design $(78.8 \%)(\mathrm{n}=26)$, Prospective study: 1 (3.0\%), RCT: 1 (3.0\%), Survey: 1 (3.0\%), Cohort study: 1 (3.0\%), NA: $3(9.1 \%)$ and $20(60.6 \%)$ of these were primary studies measuring medication adherence in diabetes patients. Most of the research recruitment locations were carried out in hospitals or public health clinics with an average sample population of $50-200$ samples. 
diabetes OR "diabetes mellitus" OR "type 2 diabetes mellitus" OR "type II diabetes mellitus" OR "type 1 diabetes mellitus" OR "type I diabetes mellitus" OR "non-insulin anti diabetic treatment" OR hyperglycemic OR "glycemic control" OR insulin OR "diabetic control" OR antidiabetic OR "Uncontrolled diabetes" OR "oral antidiabetics"

\section{AND}

adherence $O R$ persistence $O R$ persistency OR compliance OR concordance OR cooperation OR noncompliance $O R$ "non compliance" $O R$ non-compliance $O R$ "patient compliance" $O R$ nonadherence OR non-adherence OR "non adherence" OR "medication adherence" OR "guideline adherence" OR "patient compliance" OR "treatment refusal" OR "refusal of treatment" OR "diabetes medication adherence scale" OR "evaluation of adherence" OR "medication adherence scale" OR "oral medication adherence" OR "treatment adherence" OR "diabetes medication adherence scale" OR assessment OR evaluation OR assessing OR "Adherence to treatment"

\section{AND}

"oral medication adherence" OR "treatment adherence" OR "diabetes medication adherence scale" OR assessment OR evaluation OR assessing OR "Adherence to treatment" AND "Infusion Pumps" OR regimen OR "multiple daily injections" OR "insulin therapy" OR oral OR therapy OR "medication use" OR treatment OR "drug therapy" OR insulin

AND

"monitoring device" OR "electronic device" OR "self monitor" OR "self monitoring" OR "Drug Monitoring" OR "Blood Glucose Self-Monitoring" OR "Self Administration" OR "Reminders" OR "Drug Administration Schedule" OR "medication possession ratios" OR self-report

Figure 1 : Search strategies on the database Wiley Online, ScienceDirect, Scopus, and PubMed ${ }^{12}$.

856 articles detected from the search process in four databases (WILEY ONLINE $(n=51)$, SCOPUS $(n=195)$, SCIENCE DIRECT $(n=218)$, and PUBMED $(n=392)$

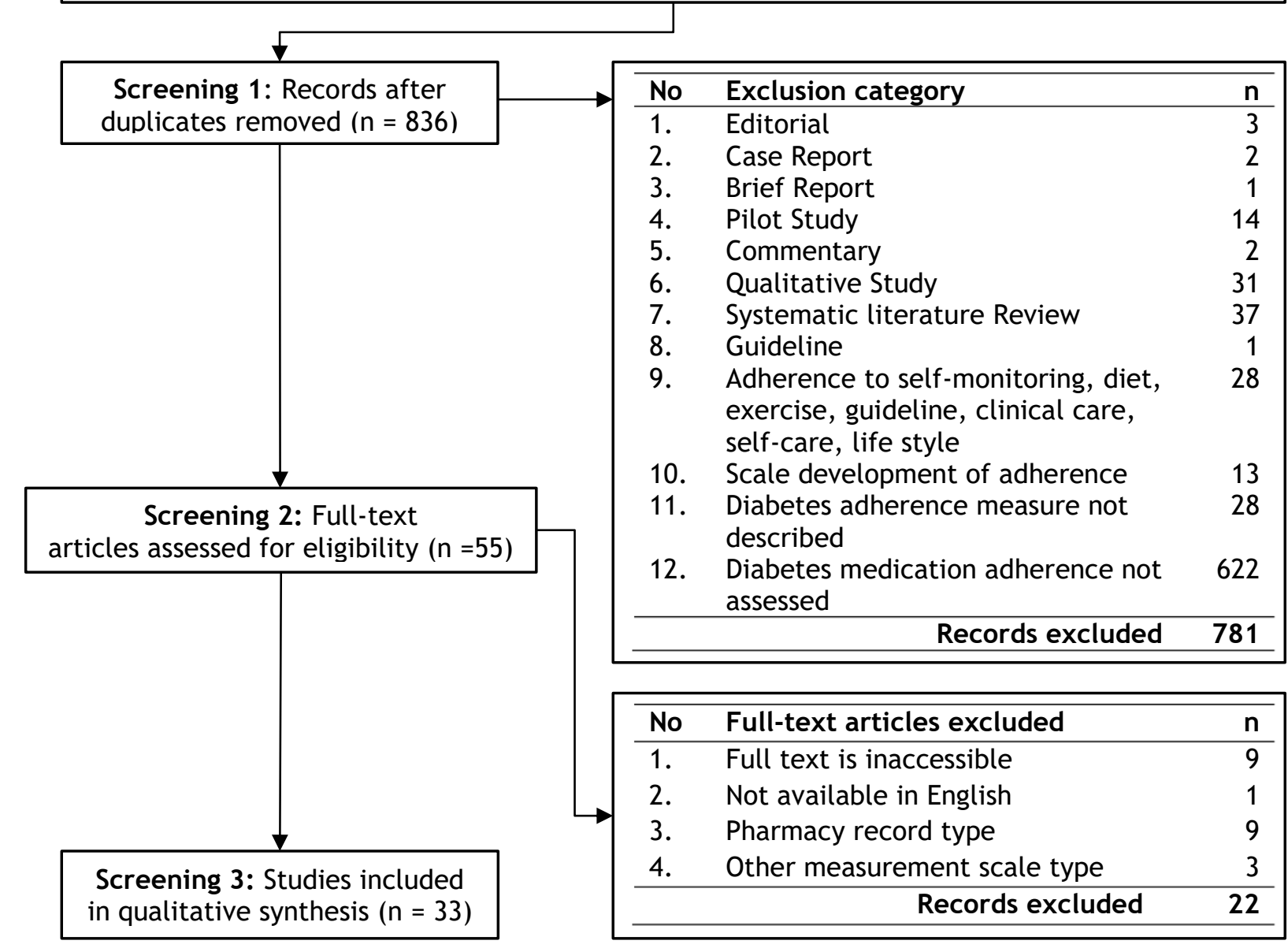

Figure 2 : PRISMA screening diagram of retrieved studies ${ }^{17}$. 


\section{Self-reported Adherence Scale Commonly Reported}

There are nine self-reported scales on 33 research on diabetic medication adherence (2009-2019). The self-reported scale identified in the research papers and used to measure medication adherence in diabetic patients:

\section{Morisky Medication Adherence Scale (MMAS-4 and MMAS-8)}

During 2009 - 2019 the self-reported scale of medication adherence in diabetic patients was dominated by the Morisky Medication Adherence Scale-8 (MMAS-8) (57.6\%) $(n=19)^{18-35}$ and Morisky Medication Adherence Scale-4 (MMAS-4) (12.1\%) $(n=4)(\text { Table } 2 a)^{36-39}$. The majority of these studies were conducted in hospitalized type 2 diabetes patients with a study period of $2-12$ months. This review found that eight studies have used the MMAS (4-item or 8-item) scale that has been independently validated by researchers or using a scale validated by other researchers. The eight studies of MMAS (4-item or 8-item) scale found a correlation between adherence levels and HbA1c or blood glucose levels ${ }^{35,37,40-45}$ (Table 3). There are at least eight versions of MMAS- 8 in various countries and languages for diabetes patients. Internal consistency values or Cronbach alpha of MMAS- 8 for diabetics ranged from 0.47 to 0.70 (Table 4) $^{15,46-53}$. The Cronbach alpha value is categorized as low - moderate, whereas if MMAS8 performed in hypertensive patients, the Cronbach alpha value is 0.83 .

\section{Brief Medication Questionnaire (BMQ)}

The BMQ scale was used by three studies in different countries (USA, Brazil, and Indonesia) with a study time of $6-19$ months $(9.1 \%)(n=3)$ (Table $2 b)^{54-56}$. All three studies were conducted in hospitals on type 2 diabetes patients. One study in Indonesia ${ }^{57}$ carried out a local language translation and adaptation process based on WHO guidelines ${ }^{14}$. In contrast, two other studies in the USA $^{54}$ and Brazil ${ }^{56}$ did not carry out this process (Table 3). The study of medication adherence used the BMQ scale in Indonesia, carried out the adaptation process and scale validation but did not analyze the predictive validity (Table 3 ). Scale adaptation and scale validation of BMQ in diabetic patients were carried out by research in Sri Lanka and Indonesia following WHOrecommended translation and cultural adaptation procedures (Table 4$)^{14,55,58}$. The Cronbach alpha values of these studies were relatively the same as the BMQ study in hypertensive patients (Table $4)^{57-59}$.

\section{Medication Compliance Questionnaire (MCQ)}

Two studies in Malaysia and Cameroon from this review used the MCQ scale $(6.1 \%)(n=2)$ (Table $2 b)^{60,61}$. The study was conducted on type 2 diabetes patients in hospitals and primary health care for $2-6$ months. The validity and reliability of the MCQ were determined by using 20 diabetes patients before use in Malaysia ${ }^{60}$, whereas the Cameroon study did not ${ }^{61}$ (Table 3). Although the research in Malaysia performed scale validation, the study did not measure clinical indicators of diabetes patients, so it was unable to determine its predictive validity. The MCQ scale was developed to measure medication adherence in diabetic patients with a Cronbach alpha value in the good category $(0.782>0.7)$.

\section{Adherence to Refill Medication Scale (ARMS) and Adherence to Refills and Medication Scale for Diabetes (ARMS-D)}

Two studies were using the ARMS $(3.2 \%)(n=1)^{62}$ and ARMS-D $(3.2 \%)(n=1)^{63}$ scales conducted in two different countries (Table 2b). One study using the ARMS scale was performed in Indonesia ${ }^{62}$, and another study using the ARMS-D scale was performed in Qatar ${ }^{63}$. Both studies were performed on diabetic patients in primary health care for 2 - 4 months. Research in Qatar finds a clear correlation between $\mathrm{HbA} 1 \mathrm{c}$ and adherence levels, whereas the Indonesian study did not measure the biological markers of diabetes patients. The ARMS scale is validated in diabetic patients and translated to the Indonesian language with the forwarding and backward translation method from the WHO research tool. The Cronbach alpha value in the validation is categorized as good and acceptable $(0.865>0.7)$. The ARMS-D scale used in Qatar also performs validation in diabetic patients using a prevalidated researcher-administered questionnaire (Table 4).

\section{General Medication Adherence Scale (GMAS)}

The GMAS scale was published in 2018 in Pakistan to measure adherence to some chronic diseases ${ }^{64}$. One study found using the GMAS scale to measure diabetes patients taking the drug $(3.0 \%)(n=1)^{39}$. The study was conducted in a state hospital in Saudi Arabia for two months using the GMAS scale, adapted using the new report from the ISPOR Task Force for Translation and Cultural Adaptation. The study found a clear correlation between the biological marker tests for diabetic patients with adherence levels (Table 4). Several studies have been conducted to test the psychometric of GMAS scale in Saudi Arabia and Pakistan (Table 4) ${ }^{65,66}$. Both translation and validation studies stated that the Arabic and English versions of GMAS were valid and reliable research instruments to measure medication adherence in patients with chronic illnesses ${ }^{65,66}$.

\section{Lebanese Medication Adherence Scale (LMAS- 14)}

The LMAS-14 instrument was developed in 2015 in Lebanon to measure adherence in chronic disease populations. It was validated in several chronic disease populations such as hypertension, diabetes, and hypothyroidism (Table 4$)^{67-70}$. One study found using the LMAS-14 scale for measuring medication adherence of patients with diabetes $(3.0 \%) \quad(n=1)(\text { Table } 2 b)^{71}$. The study was conducted in a Lebanese state hospital for four months using a scale made by previous rese- 


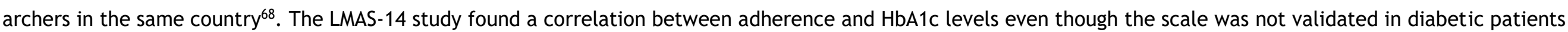
(Table 3).

Table 2a: General characteristics of included studies.

\begin{tabular}{|c|c|c|c|c|c|c|c|c|}
\hline No & Author and Research design & $\begin{array}{l}\text { Self- } \\
\text { reported } \\
\text { scale }\end{array}$ & $\begin{array}{l}\text { DM } \\
\text { Type }\end{array}$ & $\begin{array}{l}\text { Clinical } \\
\text { indicator }\end{array}$ & Country & Setting & $\begin{array}{l}\text { Duration of study } \\
\text { (Month) }\end{array}$ & $\begin{array}{l}\text { Limitations related to the adherence } \\
\text { scale }\end{array}$ \\
\hline 1. & $\begin{array}{l}\text { (Al-Qazaz et al., 2011), } \\
\text { Cross-sectional } 18\end{array}$ & MMAS-8 & T2DM & $\mathrm{HbA1c}$ & Malaysia & Hospital & 7 Month & $\begin{array}{l}\text { Overestimated and socially desirable } \\
\text { answer }\end{array}$ \\
\hline 2. & $\begin{array}{l}\text { (Hernandez-Tejada et al., } \\
\text { 2012), Cross-sectional }\end{array}$ & MMAS-8 & T2DM & Blood sugar & USA & Primary-Care & 3 Month & Not mention in the study \\
\hline 3. & $\begin{array}{l}\text { (Bailey et al., 2012), Cross- } \\
\text { sectional }^{25}\end{array}$ & MMAS-8 & $\begin{array}{l}\text { T1DM \& } \\
\text { T2DM }\end{array}$ & $\mathrm{N} / \mathrm{A}$ & $\begin{array}{l}\text { USA and } \\
\text { Mexico }\end{array}$ & $\begin{array}{l}\text { Community } \\
\text { Clinic }\end{array}$ & 3 Month & Not mention in the study \\
\hline 4. & $\begin{array}{l}\text { (Sweileh et al., 2014), Cross- } \\
\text { sectional }^{19}\end{array}$ & MMAS-8 & T2DM & $\mathrm{N} / \mathrm{A}$ & Palestina & $\begin{array}{l}\text { Primary } \\
\text { Health }\end{array}$ & 4 Month & $\begin{array}{l}\text { The scale was not translated and not } \\
\text { validated to the Arabic version }\end{array}$ \\
\hline 5. & $\begin{array}{l}\text { (Farsaei et al., 2014), Cross- } \\
\text { sectional }^{20}\end{array}$ & MMAS-8 & $\begin{array}{l}\text { T1DM \& } \\
\text { T2DM }\end{array}$ & $\mathrm{N} / \mathrm{A}$ & Iran & $\begin{array}{l}\text { Diabetes } \\
\text { Clinic }\end{array}$ & NA & Not mention in the study \\
\hline 6. & $\begin{array}{l}\text { (Sankar et al., 2015), Cross- } \\
\text { sectional }^{26}\end{array}$ & MMAS-8 & $\begin{array}{l}\text { T1DM \& } \\
\text { T2DM }\end{array}$ & Blood sugar & India & Community & 3 Month & Overestimated answer \\
\hline 7. & $\begin{array}{l}\text { (Wong et al., 2015), Cross- } \\
\text { sectional }^{21}\end{array}$ & MMAS-8 & T2DM & HbA1c & Hong Kong & Hospital & NA & Not mention in the study \\
\hline 8. & $\begin{array}{l}\text { (Jackson et al., 2015), Cross- } \\
\text { sectional }^{27}\end{array}$ & MMAS-8 & T2DM & $\mathrm{N} / \mathrm{A}$ & Nigeria & Hospital & 8 Month & Recall bias \\
\hline 9. & $\begin{array}{l}\text { (Shams et al., 2016), Cross- } \\
\text { sectional }^{22}\end{array}$ & MMAS-8 & T2DM & $\mathrm{HbA1c}$ & Pakistan & Hospital & 10 Month & Not mention in the study \\
\hline 10. & $\begin{array}{l}\text { (Alfian et al., 2016), Cross- } \\
\text { sectional }^{28}\end{array}$ & MMAS-8 & T2DM & $\mathrm{N} / \mathrm{A}$ & Indonesia & $\begin{array}{l}\text { Secondary } \\
\text { Health Care }\end{array}$ & 3 Month & Recall bias \\
\hline 11. & (Butt et al., 2016), RCT ${ }^{34}$ & MMAS-8 & T2DM & $\mathrm{HbA1c}$ & Malaysia & Hospital & 6 Month & Not mention in the study \\
\hline 12. & $\begin{array}{l}\text { (Samu et al., 2017), A } \\
\text { prospective study }\end{array}$ & MMAS-8 & T2DM & $\mathrm{HbA1c}$ & India & Hospital & 12 Month & Not mention in the study \\
\hline 13. & $\begin{array}{l}\text { (Waari et al., 2018), Cross- } \\
\text { sectional }^{35}\end{array}$ & MMAS-8 & T2DM & HbA1c & Kenya & Hospitals & 3 Month & Not mention in the study \\
\hline 14. & $\begin{array}{l}\text { (Khotkar et al., 2017), Cross- } \\
\text { sectional }^{33}\end{array}$ & MMAS-8 & T2DM & $\begin{array}{l}\text { Blood } \\
\text { glucose }\end{array}$ & India & Hospital & 12 Month & Recall bias \\
\hline 15. & $\begin{array}{l}\text { (Balasubramaniam et al., } \\
\text { 2019), Cross-sectional }{ }^{31}\end{array}$ & MMAS-8 & T2DM & HbA1c & Malaysia & Hospital & 5 Month & Recall bias \\
\hline 16. & $\begin{array}{l}\text { (Olorunfemi and Ojewole, } \\
\text { 2019), Cross-sectional }{ }^{30}\end{array}$ & MMAS-8 & $\begin{array}{l}\text { T1DM \& } \\
\text { T2DM }\end{array}$ & $\mathrm{N} / \mathrm{A}$ & Nigeria & Hospitals & NA & Not mention in the study \\
\hline
\end{tabular}


Table 2b: General characteristics of included studies.

\begin{tabular}{|c|c|c|c|c|c|c|c|c|}
\hline No & Author and Research design & $\begin{array}{l}\text { Self- } \\
\text { reported } \\
\text { scale }\end{array}$ & $\begin{array}{l}\text { DM } \\
\text { Type }\end{array}$ & $\begin{array}{l}\text { Clinical } \\
\text { indicator }\end{array}$ & Country & Setting & $\begin{array}{l}\text { Duration of study } \\
\text { (Month) }\end{array}$ & $\begin{array}{l}\text { Limitations related to the adherence } \\
\text { scale }\end{array}$ \\
\hline 17. & $\begin{array}{l}\text { (Acharya et al., 2019), Cross- } \\
\text { sectional }^{23}\end{array}$ & MMAS-8 & T2DM & $\mathrm{HbA1c}$ & India & Hospital & 2 Month & Recall bias \\
\hline 18. & $\begin{array}{l}\text { (Jannoo and Mamode Khan, } \\
\text { 2019), Cross-sectional }{ }^{32}\end{array}$ & MMAS-8 & T2DM & $\mathrm{HbA1c}$ & Malaysia & Hospitals & NA & Not mention in the study \\
\hline 19. & $\begin{array}{l}\text { (Nazir et al., 2016), Cross- } \\
\text { sectional } 72\end{array}$ & MMAS-8 & T2DM & $\mathrm{HbA1c}$ & Pakistan & Public clinic & 4 Month & Not mention in the study \\
\hline 21 & $\begin{array}{l}\text { (Grandy et al., 2013), Survey } \\
\text { study }^{38}\end{array}$ & MMAS-4 & T2DM & $\mathrm{N} / \mathrm{A}$ & USA & $\begin{array}{l}\text { General } \\
\text { Population }\end{array}$ & 24 Month & Not mention in the study \\
\hline 22. & $\begin{array}{l}\text { (Mann et al., 2009), Cohort } \\
\text { study }^{73}\end{array}$ & MMAS-4 & T2DM & $\mathrm{N} / \mathrm{A}$ & USA & Primary-Care & 7 Month & Overestimated answer \\
\hline 23. & $\begin{array}{l}\text { (Alqarni et al., 2019), Cross- } \\
\text { sectional }^{74}\end{array}$ & MMAS-4 & $\begin{array}{l}\text { T1DM \& } \\
\text { T2DM }\end{array}$ & $\mathrm{HbA} 1 \mathrm{c}$ & $\begin{array}{l}\text { Saudi } \\
\text { Arabia }\end{array}$ & $\begin{array}{l}\text { Primary } \\
\text { Health }\end{array}$ & 4 Month & Overestimated answer \\
\hline 24. & $\begin{array}{l}\text { (Kreyenbuhl et al., 2011), } \\
\text { N/A }{ }^{54}\end{array}$ & BMQ & T2DM & $\mathrm{HbA} 1 \mathrm{c}$ & USA & Hospital & 19 Month & Overestimated answer \\
\hline 26. & $\begin{array}{l}\text { (Perwitasari and Urbayatun, } \\
\text { 2016), Cross-sectional }{ }^{55}\end{array}$ & $\mathrm{BMQ}$ & T2DM & $\mathrm{N} / \mathrm{A}$ & Indonesia & Hospital & 6 Month & Not mention in the study \\
\hline 27. & $\begin{array}{l}\text { (Sufiza Ahmad et al., 2013), } \\
\text { Cross-sectional }\end{array}$ & MCQ & T2DM & $\mathrm{N} / \mathrm{A}$ & Malaysia & $\begin{array}{l}\text { Primary } \\
\text { health care }\end{array}$ & 6 Month & Not mention in the study \\
\hline 28. & $\begin{array}{l}\text { (Aminde et al., 2019), Cross- } \\
\text { sectional }^{61}\end{array}$ & MCQ & T2DM & $\mathrm{N} / \mathrm{A}$ & Kamerun & Hospital & 2 Month & Recall bias and overestimate answer \\
\hline 29. & $\begin{array}{l}\text { (Andanalusia et al., 2019), } \\
\text { Cross-sectional }{ }^{62}\end{array}$ & ARMS & T2DM & $\mathrm{N} / \mathrm{A}$ & Indonesia & $\begin{array}{l}\text { Primary } \\
\text { health care }\end{array}$ & 2 Month & Not mention in the study \\
\hline 30. & $\begin{array}{l}\text { (Jaam et al., 2018), Cross- } \\
\text { sectional }^{63}\end{array}$ & ARMS-D & $\begin{array}{l}\text { T1DM \& } \\
\text { T2DM }\end{array}$ & $\mathrm{HbA} 1 \mathrm{c}$ & Qatar & $\begin{array}{l}\text { Primary } \\
\text { Healthcare }\end{array}$ & 4 Month & Social desirability bias and recall bias \\
\hline 31. & $\begin{array}{l}\text { (AlQarni et al., 2019), Cross- } \\
\text { sectional }^{39}\end{array}$ & GMAS & T2DM & $\mathrm{HbA} 1 \mathrm{c}$ & $\begin{array}{l}\text { Saudi } \\
\text { Arabia }\end{array}$ & Hospital & 2 Month & Not mention in the study \\
\hline 32. & $\begin{array}{l}\text { (Mroueh et al., 2018), Cross- } \\
\text { sectional }^{71}\end{array}$ & LMAS-14 & T2DM & $\mathrm{HbA} 1 \mathrm{c}$ & Lebanon & Hospitals & 4 Month & Social desirability bias and recall bias \\
\hline 33. & $\begin{array}{l}\text { (Lee et al., 2017), Cross- } \\
\text { sectional }\end{array}$ & MARS-5 & T2DM & $\mathrm{HbA} 1 \mathrm{c}$ & Singapura & Primary Care & 10 Month & Not mention in the study \\
\hline
\end{tabular}


Table 3. Information of validation of adherence scale and predictive validation

\begin{tabular}{|c|c|c|c|c|}
\hline & \multicolumn{3}{|c|}{ Predictive validation (scale measurement and biological markers) } \\
\hline & & Correlated & Not correlated & N/A \\
\hline & Validated & $\begin{array}{ll}\text { 1. } & \text { (Al-Qazaz et al., 2011) MMAS-841 } \\
\text { 2. } & \text { (Sankar et al., 2015) MMAS-84 } \\
\text { 3. } & \text { (Butt et al., 2016) MMAS-8 }{ }^{43} \\
\text { 4. } & \text { (Balasubramaniam et al., 2019) } \\
& \text { MMAS-8 } \\
\text { 5. (Jannoo and Mamode Khan, 2019) } \\
\text { MMAS-8 } \\
\text { 6. (Waari et al., 2018) MMAS-8 } \\
\text { 7. (Alqarni et al., 2018) MMAS-4 } \\
\text { 8. (Aikens and Piette, 2013) MMAS-4 } \\
\text { 9. (AlQarni et al., 2019) GMAS }{ }^{39} \\
\text { 10. (Jaam et al., 2018) ARMS-D } \\
\text { 133 }\end{array}$ & - & $\begin{array}{ll}\text { 1. } & \text { (Andanalusia et al., } \\
\text { 2019) ARMS } \\
\text { 2. } \\
\text { (Ahmad et al., 2013) } \\
\text { MCQ }^{60} \\
\text { 3. (Perwitasari and } \\
\text { Urbayatun, 2016) } \\
\text { BMQ }^{57}\end{array}$ \\
\hline 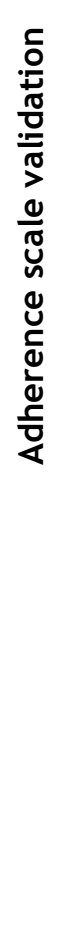 & $\begin{array}{c}\text { Not } \\
\text { validated }\end{array}$ & $\begin{array}{l}\text { 1. (Samu et al., 2017) MMAS-8 } \\
\text { 2. (Lee et al., 2017) MARS-575 } \\
\text { 3. (Mroueh et al., 2018) LMAS-14 } 14^{71}\end{array}$ & $\begin{array}{l}\text { 1. (Wong et al., } \\
\text { 2015) MMAS- } \\
8^{21} \\
\text { 2. (Khotkar et } \\
\text { al., 2017) } \\
\text { MMAS-8 } \\
\text { 3. (Acharya et } \\
\text { al., 2017) } \\
\text { MMAS-8 } \\
\text { 4. (Nazir et al., } \\
\text { 2016) MMAS- } \\
8^{72} \\
\text { 5. (Istilli et al., } \\
\text { 2015) BMQ56 } \\
\text { 6. (Kreyenbuhl } \\
\text { et al., 2011) } \\
\text { BMQ }^{54}\end{array}$ & $\begin{array}{l}\text { 1. (Hernandez-Tejada et } \\
\text { al., 2012) MMAS-8 } \\
\text { 2. (Bailey et al., 2012) } \\
\text { MMAS- } 8^{25} \\
\text { 3. (Sweileh et al., 2014) } \\
\text { MMAS-8 } \\
\text { 4. (Farsaei et al., 2014) } \\
\text { MMAS-8 } \\
\text { 5. (Jackson et al., 2015) } \\
\text { MMAS-8 } \\
\text { 6. (Shams et al., 2016) } \\
\text { MMAS-8 } \\
\text { 7. (Alfian et al., 2016) } \\
\text { MMAS-8 } \\
\text { 8. (Olorunfemi and } \\
\text { Ojewole, 2019) MMAS- } \\
\text { 8 }^{30} \\
\text { 9. (Grandy et al., 2013) } \\
\text { MMAS-8 } \\
\text { 10. (Mann et al., 2009) } \\
\text { MMAS-8 } \\
\text { 11. (Aminde et al., 2019) } \\
\text { MCQ }{ }^{61}\end{array}$ \\
\hline & N/A & - & - & \\
\hline
\end{tabular}

N/A: not available; MMAS-4: Morisky Medication Adherence Scale 4; MMAS-8: Morisky Medication Adherence Scale 8; BMQ: Brief Medication Questionnaire; MCQ: Medication Compliance Questionnaire; ARMS: Adherence to Refill Medication Scale; ARMS-D: Adherence to Refills and Medication Scale for Diabetes; GMAS: General Medication Adherence Scale; LMAS-14: Lebanese Medication Adherence Scale 14; MARS-5: Medication Adherence Report Scale.

Medication Adherence Report Scale (MARS-5) The MARS- 5 scale is a modification of the MARS10 scale, which measures patients' medication intake with psychotic disorders ${ }^{76}$. The results of the modification eliminated five questions that were irrelevant in diabetic patients. MARS- 5 was used by one study $(3.0 \%)(n=1)$ in Singapore as a scale to measure adherence to diabetic patients receiving large amounts of medication $(\text { Table } 2 b)^{77}$. MARS-5 has been validated in various clinical settings and used in several clinical trials to determine adherence. However, the study using MARS- 5 in a Singapore diabetic population without any prior scale validation $(\text { Table } 4)^{77-79}$. 
Table 4: Self-reported scale for medication adherence in diabetic patients.

\begin{tabular}{|c|c|c|c|c|c|c|}
\hline No & $\begin{array}{l}\text { Self- } \\
\text { reported } \\
\text { Adherence } \\
\text { Scale }\end{array}$ & $\begin{array}{l}\text { Original } \\
\text { language }\end{array}$ & $\begin{array}{l}\text { Population in } \\
\text { initial } \\
\text { validation } \\
\text { study }\end{array}$ & $\begin{array}{l}\text { The Cronbach's } \\
\text { a value in initial } \\
\text { validation study }\end{array}$ & Validation processes in the diabetic population & $\begin{array}{l}\text { The Cronbach's } \\
\text { a value in } \\
\text { diabetic patients } \\
\text { (Country) }\end{array}$ \\
\hline 1 & MMAS-8 $8^{80}$ & English & Hypertension & 0.83 & $\begin{array}{l}\text { Validated in diabetic population and translated to the } \\
\text { Malaysian, Thai, Spanish, English (American and } \\
\text { Singaporean), Arabic, Korean, French language with } \\
\text { forward and backward translation method from the } \\
\text { Report of the ISPOR Task Force for Translation and } \\
\text { Cultural Adaptation }{ }^{15,46-53} \text {. }\end{array}$ & $\begin{array}{l}0.675 \text { (Malaysia) } \\
0.61 \text { (Thailand) } \\
0.4 \text { (Spain) } \\
0.68 \text { (America) } \\
0.65 \text { (Singapore) } \\
0.70 \text { (Arab) } \\
0.66 \text { (Korea) } \\
0.47 \text { (French) }\end{array}$ \\
\hline 2 & MMAS- $4^{81}$ & English & Hypertension & 0.61 & $\begin{array}{l}\text { Validated in diabetic population and translated to the } \\
\text { Arabic language with AHRQ translation method }{ }^{16,82} \text {. }\end{array}$ & $0.76(\mathrm{Arab})$ \\
\hline 3 & $\mathrm{BMQ}^{59}$ & English & Hypertension & 0.66 & $\begin{array}{l}\text { Validated in diabetic patients and translated to the } \\
\text { Indonesian language and Sinhalese language (Sri Lanka) } \\
\text { with forwarding and backward translation method from } \\
\text { the WHO research tool }{ }^{14,57,58} \text {. }\end{array}$ & $\begin{array}{l}0.775 \text { (Indonesia) } \\
0.65 \text { (Sri Lanka) }\end{array}$ \\
\hline 4 & $M C Q^{83}$ & Malay & Diabetes & 0.782 & $\begin{array}{l}\text { An internal consistency test was done by using } 20 \text { diabetic } \\
\text { patients }{ }^{83} \text {. }\end{array}$ & 0.782 (Malaysia) \\
\hline 5 & ARMS $^{84}$ & English & Hypertension & 0.814 & $\begin{array}{l}\text { Validated in diabetic patients and translated to the } \\
\text { Indonesian language with forwarding and backward } \\
\text { translation method from the WHO research tool }{ }^{14,85} \text {. }\end{array}$ & 0.865 (Indonesia) \\
\hline 6 & ARMS-D 86 & English & Diabetes & 0.86 & $\begin{array}{l}\text { Validated in diabetic patients using a pre-validated } \\
\text { researcher-administered questionnaire }{ }^{86} \text {. }\end{array}$ & 0.86 (English) \\
\hline 7 & GMAS $^{64}$ & Urdu & Chronic illness & 0.84 & $\begin{array}{l}\text { Validated in diabetic population and translated to the } \\
\text { Arabic and English language with forwarding and } \\
\text { backward translation method from the Report of the } \\
\text { ISPOR Task Force for Translation and Cultural } \\
\text { Adaptation }{ }^{15,65,66} \text {. }\end{array}$ & $\begin{array}{l}0.865 \text { (Arabic) } \\
0.82 \text { (English) }\end{array}$ \\
\hline 8 & LMAS- $14^{68}$ & Arabic & Hypertension & 0.695 & Not validated in diabetic patients & $\mathrm{N} / \mathrm{A}$ \\
\hline 9 & MARS- $5^{76}$ & English & Schizophrenia & 0.75 & Not validated in diabetic patients & $\mathrm{N} / \mathrm{A}$ \\
\hline
\end{tabular}

N/A: not available; MMAS-4: Morisky Medication Adherence Scale 4; MMAS-8: Morisky Medication Adherence Scale 8; BMQ: Brief Medication Questionnaire; MCQ: Medication Compliance Questionnaire; ARMS: Adherence to Refill Medication Scale; ARMS-D: Adherence to Refills and Medication Scale for Diabetes; GMAS: General Medication Adherence Scale; LMAS-14: Lebanese Medication Adherence Scale 14; MARS-5: Medication Adherence Report Scale; ISPOR: The Professional Society for Health Economics and Outcomes Research; AHRQ: Agency for Healthcare Research and Quality; WHO: World Health Organization 
This systematic review summarizes self-reported medication adherence scales in diabetic patients in the original study published from 2009 to 2019. The review has identified 33 studies from different countries and found new scales developed to measure medication adherence rates in the diabetic patient population (Table $4)^{64}$. The scale used in 33 research is the original type of medication adherence scales (MMAS-8, MMAS-4, BMQ, MCQ, ARMS, GMAS, and LMAS-14) or modified medication adherence scales (ARMS-D and MARS-5). Most research on medication adherence used the MMAS- 8 self-reported scale as translation and adaptation to the local or used in its original form. It is the most studied and validated scale for several chronic diseases, including diabetes. MMAS- 8 has been performed on psychometric tests in eight different diabetic populations and has acceptable internal consistency, excellent test-retest reliability. However, it showed moderate sensitivity and specificity when used in diabetic patients ${ }^{15,46-53}$ (Table 4).

\section{DISCUSSION}

This review provides information on the various self-reported scales that are the most broadly used in diabetic medication adherence research. Most studies used a validated scale through previous psychometric tests, modified the previous scale, or used the scale validated in other countries with another disease. They used the scale in a limited context because there were no psychometric studies in the appropriate population and conditions. Psychometric tests on an established adherence scale are still needed, even for a predetermined compliance scale, because validity is not on the adherence scale itself. However, it characterizes conclusions derived from data generated using the adherence scale in a particular context ${ }^{87}$. Studies using validated scales generally find clear correlations between the results of the adherence measures and HbA1c level (Table 3) 18,31,32,34,35,37,39,45,63,74. However, several studies stated a correlation even though they did not use a validated scale (Table 3$)^{29,71,77}$. Psychometric testing is necessary because the question's characteristics, the response to the scale, and the measurement time could impact the results ${ }^{15,88}$. Most research in this review uses the validity tests that have been carried out by other researchers in settings and populations that differ from the population to be studied (Table 4). These differences may reduce adherence measures in diabetic patients, as each scale was constructed and validated in a specific patient population ${ }^{15}$. It should be understood that different scales are needed for diverse populations, contexts, and conditions. These findings should be of particular concern to researchers and clinicians who will perform studies on medication adherence.
Measuring medication adherence in diabetic patients using a self-reported scale is a substantial challenge. First, the absence of gold standard measurement; secondly, the primary therapeutic outcome measures, namely blood glucose status or HbA1c, did not always correlate with the treatment adherence level as found in this review ${ }^{21,23,33,54,56,72}$. This review found several studies in Asia and America concluded that MMAS8 scale scores ${ }^{21,23,33,72}$ and $\mathrm{BMQ}^{54,56}$ did not correlate with the clinical outcome. Most studies did not measure $\mathrm{HbA} 1 \mathrm{c}$ levels in their research populations as a comparison for the objective scale. The comparison helps assess scale accuracy based on correlation analysis between scale measurement and $\mathrm{HbA} 1 \mathrm{c}$ data. That correlation is a predictive validity that an adherence scale has adequate specificity and sensitivity to measure medication adherence in patients with diabetes ${ }^{89}$. A clear correlation between self-reported adherence levels and glycemic regulation implied that the scale could separate patients with (or without) regulated blood glucose using HbA1c or blood glucose levels.

A limitation of the self-reported scale mentioned in the study was the possibility of patients overestimating their adherence ratings because of the perceived benefits of high adherence levels, questions that the respondent did not understand, and patients' failure to remember or not they took medication ${ }^{18,19,21,27,28,33,38,39,54,56,60,61,71,75}$ (Table 2a and Table $2 b$ ). For these reasons, the results of self-report scales may experience a limitation with an unrealistic perfect adherence recorded by most respondents. One way to overcome this is by implementing an adherence scale selection criteria based on the population's characteristics and research purposes. These criteria may include a method, study design, patient population, and research resource 88,90 . Medication adherence is a complex problem; therefore, some studies suggest combining two or more measurement categories according to measurement objectives $88,90,91$. For clinical purposes, it is advisable to use a combination of several types of indirect measurements because they are less expensive. For research purposes, it is advisable to use a combination of direct and indirect measurements. Using these criteria and combinations is possible to overcome the limitations of the self-reported scale. It may be necessary to develop self-reported scales for specific populations for specific diseases for more accurate measurements.

The following recommendations could be applied to medication adherence studies: (1) Using a selfreport medication adherence scale that was validated in a population of disease, sociodemographic conditions, and language that was relatively the same as the population to be studied or performed scale validation on the population studied which is the best practice recommended by psychometrics ${ }^{87}$; (2) Measuring 
the biological marker of disease using an appropriate instrument for assessing scale accuracy as predictive validity'; (3) Combining two or more types of medication adherence measurement strategies ${ }^{88,90,91}$. Our review emphasizes the importance of understanding the strengths and weaknesses inherent in using selfreport treatment adherence measures. This review also emphasizes using a self-report adherence scale validated based on standard validation test guidelines. Finally, we would like to point out that our study may have limitations of the systematic review process. We did not include unpublished studies, and our findings may be distorted by publication bias. Several adherence studies did not analyze the correlation between adherence measures and $\mathrm{HbA} 1 \mathrm{c}$ because medication adherence was not the study's primary outcome. Therefore, it is desirable to undertake a further specific review of medication adherence as the primary outcome.

\section{CONCLUSION}

In conclusion, while this is not a comprehensive review of all the methods used in adherence studies, it does provide information on the various types of self-reported scales that can be applied to diabetic patients. The MMAS-8 self-report scale is the most widely used in diabetes patients; however, evidence of adequate psychometric testing is needed to use it in diabetes patients. Choosing the appropriate scale requires several considerations, such as using specific selfreported scales and performing a scale validation, using the biological marker of diabetes (blood glucose or HbA1c), and perform a combination of other direct or indirect methods. Creating and developing a new scale according to the predictor factors in a particular disease population could be another alternative.

\section{ACKNOWLEDGEMENT}

The Indonesia Endowment Fund for Education (BUDI DN and LPDP) supports this systemic analysis.

\section{COMPETING INTEREST}

The author states that there is no conflict of interest. The funder has no role or influence in the study design, collection, analysis, or interpretation of data, especially in scriptwriting or the decision to publish the results.

\section{REFERENCES}

1. Saeedi P, Petersohn I, Salpea P, Malanda B, Karuranga $S$, Unwin N, et al. Global and regional diabetes prevalence estimates for 2019 and projections for 2030 and 2045: Results from the International Diabetes Federation Diabetes Atlas, 9th edition.
Diabetes Research and Clinical Practice. 2019 Nov; $157: 107843$.

2. Verhulst MJL, Loos BG, Gerdes VEA, Teeuw WJ. Evaluating all potential oral complications of diabetes mellitus. Frontiers in Endocrinology. 2019;10(56).

3. Seuring $T$, Archangelidi $O$, Suhrcke $M$. The Economic Costs of Type 2 Diabetes: A Global Systematic Review. PharmacoEconomics. 2015;33(8):811-31.

4. Khunti K, Seidu S, Kunutsor S, Davies M. Association between adherence to pharmacotherapy and outcomes in type 2 diabetes: A meta-analysis. Diabetes Care. 2017;40(11):1588-96.

5. Al-lela OQB, Abdulkareem RA, AL-Mufti L, Kamal N, Qasim S, Sagvan R. Medication Adherence Among Diabetic Patients in Developing Countries: Review of Studies. Systematic Reviews in Pharmacy. 2020;11(8):6.

6. Odegard PS, Capoccia K. Medication Taking and Diabetes A Systematic Review of the Literature. Diabetes Educ. 2007 Nov;33(6):1014-29.

7. Meddings J, Kerr EA, Heisler M, Hofer TP. Physician assessments of medication adherence and decisions to intensify medications for patients with uncontrolled blood pressure: Still no better than a coin toss. BMC Health Services Research. 2012;12(1):1.

8. Clifford S, Perez-Nieves M, Skalicky AM, Reaney M, Coyne KS. A systematic literature review of methodologies used to assess medication adherence in patients with diabetes. Current Medical Research and Opinion. 2014 Jun 1;30(6):1071-85.

9. Gonzalez JS, Schneider HE. Methodological Issues in the Assessment of Diabetes Treatment Adherence. Curr Diab Rep. 2011 Dec;11(6):472-9.

10. Kristina SA, Wulandari GP. Medication adherence using self-report measures among chronic disease patients: A review. International Journal of Pharmaceutical Research. 2020 Jan 1;12.

11. Bramer WM, Rethlefsen ML, Kleijnen J, Franco $\mathrm{OH}$. Optimal database combinations for literature searches in systematic reviews: a prospective exploratory study. Syst Rev. 2017 Dec;6(1):245. 
12. Eriksen $M B$, Frandsen TF. The impact of patient, intervention, comparison, outcome (PICO) as a search strategy tool on literature search quality: a systematic review. jmla [Internet]. 2018 Oct 4 [cited 2020 Dec 21];106(4). Available from: http://jmla.pitt.edu/ojs/jmla/article/view /345

13. National Institutes of Health. Quality Assessment Tool for Observational Cohort and Cross-Sectional Studies [Internet]. National Heart, Lung, and Blood Institute. 2014. Available from: https: / /www.nhlbi.nih.gov/healthtopics/study-quality-assessment-tools

14. WHO. Process of translation and adaptation of instruments. World Health Organization. 2015.

15. Wild D, Grove A, Martin M, Eremenco S, McElroy S, Verjee-Lorenz A, et al. Principles of Good Practice for the Translation and Cultural Adaptation Process for PatientReported Outcomes (PRO) Measures: Report of the ISPOR Task Force for Translation and Cultural Adaptation. Value in Health. 2005 Mar;8(2):94-104.

16. Agency for Healthcare Research and Quality. Translation Guidelines for the AHRQ Surveys on Patient Safety Culture [Internet]. The Agency for Healthcare Research and Quality's (AHRQ). 2015. Available from: https://www.ahrq.gov/sites/default/files/ wysiwyg/professionals/quality-patientsafety/patientsafetyculture/resources/tran sguide.pdf

17. Moher D, Liberati A, etzlaff JT, Altman DG. Preferred Reporting Items for Systematic Reviews and Meta-Analyses: The PRISMA Statement. PLoS Med. 2009 Jul;6(7):1-6.

18. Al-Qazaz HK, Sulaiman SA, Hassali MA, Shafie AA, Sundram S, Al-Nuri R, et al. Diabetes knowledge, medication adherence and glycemic control among patients with type 2 diabetes. International Journal of Clinical Pharmacy. 2011;33(6):1028-35.

19. Sweileh WM, Zyoud SH, Abu Nab'A RJ, Deleq MI, Enaia MI, Nassar SM, et al. Influence of patients' disease knowledge and beliefs about medicines on medication adherence: Findings from a cross-sectional survey among patients with type 2 diabetes mellitus in Palestine. BMC Public Health. 2014;14(1):1-8.

20. Farsaei S, Radfar M, Heydari Z, Abbasi F, Qorbani M. Insulin adherence in patients with diabetes: Risk factors for injection omission. Primary Care Diabetes. 2014;8(4):338-45.

21. Wong MCS, Wu CHM, Wang HHX, Li HW, Hui EMT, Lam AT, et al. Association between the 8-item Morisky medication adherence scale (MMAS-8) score and glycaemic control among Chinese diabetes patients. Journal of Clinical Pharmacology. 2015;55(3):279-87.

22. Shams N, Amjad S, Kumar N, Ahmed W, Saleem F. Drug Non-Adherence In Type 2 Diabetes Mellitus; Predictors And Associations. Journal of Ayub Medical College, Abbottabad: JAMC. 2016;28(2):302-7.

23. Acharya AS, Gupta E, Prakash N, Singhal N. Self-reported adherence to medication among patients with type II diabetes mellitus attending a tertiary care hospital of delhi. Journal of Association of Physicians of India. 2019;67:26-9.

24. Hernandez-Tejada MA, Campbell JA, Walker RJ, Smalls BL, Davis KS, Egede LE. Diabetes empowerment, medication adherence and self-care behaviors in adults with type 2 diabetes. Diabetes Technology and Therapeutics. 2012;14(7):630-4.

25. Bailey GR, Barner JC, Weems JK, Leckbee G, Solis R, Montemayor D, et al. Assessing Barriers to Medication Adherence in Underserved Patients With Diabetes in Texas. The Diabetes Educator. 2012;38(2):271-9.

26. Sankar U V., Lipska K, Mini GK, Sarma PS, Thankappan KR. The adherence to medications in diabetic patients in rural Kerala, India. Asia-Pacific Journal of Public Health. 2015;27(2):NP513-23.

27. Jackson IL, Adibe MO, Okonta MJ, Ukwe C V. Medication adherence in type 2 diabetes patients in Nigeria. Diabetes Technology and Therapeutics. 2015;17(6):398-404.

28. Alfian SD, Sukandar H, Lestari K, Abdulah R. Medication Adherence Contributes to an Improved Quality of Life in Type 2 Diabetes Mellitus Patients: A Cross-Sectional Study. Diabetes Therapy. 2016;7(4):755-64.

29. Samu AM, Amirthalingam PS, Mohammed OS. Assessment of patient medication adherence among the type 2 diabetes mellitus population with peripheral diabetic neuropathy in South India. Journal of Taibah University Medical Sciences. 2017;12(2):164-8. 
30. Olorunfemi O, Ojewole F. Medication belief as correlate of medication adherence among patients with diabetes in Edo State, Nigeria. Nursing Open. 2019;6(1):197-202.

31. Balasubramaniam S, Lim SL, Goh LH, Subramaniam S, Tangiisuran B. Evaluation of illness perceptions and their associations with glycaemic control, medication adherence and chronic kidney disease in type 2 diabetes mellitus patients in Malaysia. Diabetes and Metabolic Syndrome: Clinical Research and Reviews. 2019;13(4):2585-91.

32. Jannoo Z, Mamode Khan N. Medication Adherence and Diabetes Self-Care Activities among Patients with Type 2 Diabetes Mellitus. Value in Health Regional Issues. 2019;18(18):30-5.

33. Khotkar K, Chaudhari S, Jadhav PR, Deshmukh YA. Assessment of Medication Adherence in Type II Diabetic Patients: A Cross-sectional Study. MGM Journal of Medical Sciences. 2017 Jun;4(2):65-9.

34. Butt M, Mhd Ali A, Bakry MM, Mustafa N. Impact of a pharmacist led diabetes mellitus intervention on $\mathrm{HbA1C}$, medication adherence and quality of life: A randomised controlled study. Saudi Pharmaceutical Journal. 2016;24(1):40-8.

35. Waari G, Mutai J, Gikunju J. Medication adherence and factors associated with poor adherence among type 2 diabetes mellitus patients on follow-up at Kenyatta National Hospital, Kenya. PAMJ [Internet]. 2018 [cited 2021 Feb 14];29. Available from: http://www. panafrican-medjournal.com/content/article/29/82/full/

36. Mann DM, Ponieman D, Leventhal $\mathrm{H}$, Halm EA. Predictors of adherence to diabetes medications: The role of disease and medication beliefs. Journal of Behavioral Medicine. 2009;32(3):278-84.

37. Aikens JE, Piette JD. Longitudinal association between medication adherence and glycaemic control in Type 2 diabetes. Vol. 30, Diabetic Medicine. 2013. p. 338-44.

38. Grandy S, Fox KM, Hardy E, Bays H, Bazata DD, Gavin JR, et al. Association of Weight Loss and Medication Adherence Among Adults With Type 2 Diabetes Mellitus: SHIELD (Study to Help Improve Early evaluation and management of risk factors Leading to Diabetes). Current Therapeutic Research Clinical and Experimental. 2013;75:77-82.
39. AlQarni K, AlQarni EA, Naqvi AA, AlShayban DM, Ghori SA, Haseeb A, et al. Assessment of medication adherence in Saudi patients with type II diabetes mellitus in Khobar city, Saudi Arabia. Frontiers in Pharmacology. 2019;10(November):1-9.

40. Alqarni AM, Alrahbeni T, Al Qarni A, Al Qarni $\mathrm{HM}$. Adherence to diabetes medication among diabetic patients in the Bisha governorate of Saudi Arabia \&ndash; a crosssectional survey. PPA. 2018 Dec;Volume 13:63-71.

41. Al-Qazaz HKh, Sulaiman SA, Hassali MA, Shafie AA, Sundram S, Al-Nuri R, et al. Diabetes knowledge, medication adherence and glycemic control among patients with type 2 diabetes. Int J Clin Pharm. 2011 Dec;33(6):1028-35.

42. Balasubramaniam S, Lim SL, Goh LH, Subramaniam S, Tangiisuran B. Evaluation of illness perceptions and their associations with glycaemic control, medication adherence and chronic kidney disease in type 2 diabetes mellitus patients in Malaysia. Diabetes \& Metabolic Syndrome: Clinical Research \& Reviews. 2019 Jul;13(4):2585-91.

43. Butt M, Mhd Ali A, Bakry MM, Mustafa N. Impact of a pharmacist led diabetes mellitus intervention on $\mathrm{HbA} 1 \mathrm{C}$, medication adherence and quality of life: A randomised controlled study. Saudi Pharmaceutical Journal. 2016 Jan;24(1):40-8.

44. Jannoo Z, Mamode Khan N. Medication Adherence and Diabetes Self-Care Activities Among Patients With Type 2 Diabetes Mellitus. Value in Health Regional Issues. 2019 May; 18:30-5.

45. Sankar UV, Lipska K, Mini GK, Sarma PS, Thankappan KR. The Adherence to Medications in Diabetic Patients in Rural Kerala, India. Asia Pac J Public Health. 2015 Mar;27(2):513-23.

46. Sakthong $P, \quad$ Chabunthom $R$, Charoenvisuthiwongs R. Psychometric Properties of the Thai Version of the 8-item Morisky Medication Adherence Scale in Patients with Type 2 Diabetes. Ann Pharmacother. 2009 May;43(5):950-7.

47. Lee $\mathrm{W}-\mathrm{Y}$, Ahn J, Kim J-H, Hong Y-P, Hong SK, Kim YT, et al. Reliability and validity of a self-reported measure of medication adherence in patients with type 2 diabetes mellitus in Korea. J Int Med Res. 2013 Aug;41(4):1098-110. 
48. Al-Qazaz HKh, Hassali MA, Shafie AA, Sulaiman SA, Sundram S, Morisky DE. The eight-item Morisky Medication Adherence Scale MMAS: Translation and validation of the Malaysian version. Diabetes Research and Clinical Practice. 2010 Nov;90(2):21621.

49. Tandon S, Chew M, Eklu-Gadegbeku CK, Shermock KM, Morisky DE. Validation and psychometric properties of the 8-item Morisky Medication Adherence Scale (MMAS8 ) in Type 2 diabetes patients in sub-Saharan Africa. Diabetes Research and Clinical Practice. 2015 Nov; 110(2):129-36.

50. Ashur ST, Shamsuddin K, Shah SA, Bosseri S, Morisky DE. Reliability and known-group validity of the Arabic version of the 8-item Morisky Medication Adherence Scale among type 2 diabetes mellitus patients. Easter Mediterr Health J. 2015 Oct 1;21(10):722-8.

51. Martinez-Perez $P$, Orozco-Beltrán D, Pomares-Gomez F, Hernández-Rizo JL, Borras-Gallen A, Gil-Guillen VF, et al. Validation and psychometric properties of the 8-item Morisky Medication Adherence Scale (MMAS-8) in type 2 diabetes patients in Spain. Atención Primaria. 2021 Feb;53(2):101942.

52. Wang Y, Lee J, Toh MPHS, Tang WE, Ko Y. Validity and reliability of a self-reported measure of medication adherence in patients with Type 2 diabetes mellitus in Singapore: Validation of a medication adherence measure in Singapore. Diabetic Medicine. 2012 Sep;29(9):e338-44.

53. DiBonaventura $M$, Wintfeld $N$, Huang J, Goren A. The association between nonadherence and glycated hemoglobin among type 2 diabetes patients using basal insulin analogs. PPA. 2014 Jun;873.

54. Kreyenbuhl J, Leith J, Medoff DR, Fang LJ, Dickerson FB, Brown $\mathrm{CH}$, et al. A comparison of adherence to hypoglycemic medications between Type 2 diabetes patients with and without serious mental illness. Psychiatry Research. 2011;188(1):109-14.

55. Perwitasari DA, Urbayatun S. Treatment Adherence and Quality of Life in Diabetes Mellitus Patients in Indonesia. SAGE Open. 2016;6(2).

56. Istilli PT, Pereira MCA, Teixeira CR de S, Zanetti ML, Becker TAC, Marques JVP. Treatment adherence to oral glucoselowering agents in people with diabetes: Using the Brief Medication Questionnaire.
Journal
of
Diabetes
Nursing.
2015;19(9):340-8.

57. Perwitasari DA, Urbayatun S. Treatment Adherence and Quality of Life in Diabetes Mellitus Patients in Indonesia. SAGE Open. 2016 Apr 20;6(2):215824401664374.

58. Ranasinghe $P$, Jayawardena $R$, Katulanda $P$, Constantine GR, Ramanayake V, Galappatthy P. Translation and Validation of the Sinhalese Version of the Brief Medication Questionnaire in Patients with Diabetes Mellitus. Journal of Diabetes Research. 2018;2018:1-7.

59. Ben AJ, Neumann CR, Mengue SS. The Brief Medication Questionnaire and MoriskyGreen Test to evaluate medication adherence. Rev Saúde Pública. 2012 Apr;46(2):279-89.

60. Sufiza Ahmad N, Ramli A, Islahudin F, Paraidathathu T. Medication adherence in patients with type 2 diabetes mellitus treated at primary health clinics in Malaysia. Patient Preference and Adherence. 2013;7:525-30.

61. Aminde $L N$, Tindong $M$, Ngwasiri CA, Aminde JA, Njim T, Fondong AA, et al. Adherence to antidiabetic medication and factors associated with non-adherence among patients with type-2 diabetes mellitus in two regional hospitals in Cameroon. BMC Endocrine Disorders. 2019;19(1).

62. Andanalusia $M$, Athiyah $U$, Nita $Y$. Medication adherence in diabetes mellitus patients at Tanjung Karang Primary Health Care Center, Mataram. Journal of Basic and Clinical Physiology and Pharmacology. 2019;0(0).

63. Jaam M, Mohamed Ibrahim MI, Kheir N, Hadi MA, Diab MI, Awaisu A. Assessing prevalence of and barriers to medication adherence in patients with uncontrolled diabetes attending primary healthcare clinics in Qatar. Primary Care Diabetes. 2018;12(2):116-25.

64. Naqvi AA, Hassali MA, Rizvi M, Zehra A, Iffat $W$, Haseeb A, et al. Development and Validation of a Novel General Medication Adherence Scale (GMAS) for Chronic Illness Patients in Pakistan. Front Pharmacol. 2018 Oct 9;9:1124.

65. Naqvi AA, Mahmoud MA, AlShayban DM, Alharbi FA, Alolayan SO, Althagfan S, et al. Translation and validation of the Arabic version of the General Medication Adherence Scale (GMAS) in Saudi patients 
with chronic illnesses. Saudi Pharmaceutical Journal. 2020 Sep;28(9):1055-61.

66. Naqvi AA, Hassali MA, Jahangir A, Nadir MN, Kachela B. Translation and validation of the English version of the general medication adherence scale (GMAS) in patients with chronic illnesses. Journal of Drug Assessment. 2019 Jan 1;8(1):36-42.

67. Assi SA, Slaybi Y, Salameh P, Saleh N. Development of A Scoring System to Measure Drug Compliance Among Patients With Chronic Diseases In Lebanon. Journal of Hypertension. 2015 Jun; 33:e281.

68. Bou Serhal R, Salameh P, Wakim N, Issa C, Kassem B, Abou Jaoude L, et al. A New Lebanese Medication Adherence Scale: Validation in Lebanese Hypertensive Adults. International Journal of Hypertension. 2018;2018:1-7.

69. Hallit S, Haddad C, Sacre H, Rahme C, Akel $M$, Saleh $N$, et al. Medication adherence among Lebanese adult patients with hypothyroidism: Validation of the Lebanese Medication Adherence Scale and correlates. Clinical Epidemiology and Global Health. 2021 Jan;9.

70. Ibrahim L, Ibrahim L, Hallit S, Salameh P, Sacre $H$, Akel $M$, et al. Validation of the Lebanese Medication Adherence Scale among Lebanese diabetic patients. Int J Clin Pharm. 2020 Nov;

71. Mroueh L, Ayoub D, El-Hajj M, Awada S, Rachidi S, Zein S, et al. Evaluation of medication adherence among lebanese diabetic patients. Pharmacy Practice. 2018;16(4):1-8.

72. Nazir SUR, Hassali MA, Saleem F, Bashir S, Aljadhey $H$. Disease related knowledge, medication adherence and glycaemic control among patients with type 2 diabetes mellitus in Pakistan. Primary Care Diabetes. 2016 Apr;10(2):136-41.

73. Mann DM, Ponieman D, Leventhal H, Halm EA. Predictors of adherence to diabetes medications: the role of disease and medication beliefs. J Behav Med. 2009 Jun;32(3).

74. Alqarni AM, Alrahbeni T, Al Qarni A, Al Qarni HM. Adherence to diabetes medication among diabetic patients in the Bisha governorate of Saudi Arabia - a crosssectional survey. Patient Preference and Adherence. 2019;13:63-71.
75. Lee CS, Tan JHM, Sankari U, Koh YLE, Tan NC. Assessing oral medication adherence among patients with type 2 diabetes mellitus treated with polytherapy in a developed Asian community: a crosssectional study. BMJ Open. 2017 Sep;7(9):e016317.

76. Horne R, Weinman J. Self-regulation and Self-management in Asthma: Exploring The Role of Illness Perceptions and Treatment Beliefs in Explaining Non-adherence to Preventer Medication. Psychology \& Health. 2002 Jan; 17(1):17-32.

77. Lee CS, Tan JHM, Sankari U, Koh YLE, Tan NC. Assessing oral medication adherence among patients with type 2 diabetes mellitus treated with polytherapy in a developed Asian community: A crosssectional study. BMJ Open. 2017;7(9):1-7.

78. Ladova K, Matoulkova P, Zadak Z, Macek K, Vyroubal P, Vlcek J, et al. Self-reported adherence by MARS-CZ reflects LDL cholesterol goal achievement among statin users: validation study in the Czech Republic: Self-reported and objective adherence. J Eval Clin Pract. 2014 Oct;20(5):671-7.

79. Brooks TL, Leventhal H, Wolf MS, O'Conor R, Morillo J, Martynenko M, et al. Strategies Used by Older Adults with Asthma for Adherence to Inhaled Corticosteroids. J GEN INTERN MED. 2014 Nov;29(11):1506-12.

80. Morisky DE, Ang A, Krousel-Wood M, Ward HJ. Predictive validity of a medication adherence measure in an outpatient setting. J Clin Hypertens (Greenwich). 2008 May;10(5):348-54.

81. Morisky DE, Green LW, Levine DM. Concurrent and Predictive Validity of a Selfreported Measure of Medication Adherence. Med Care. 1986 Jan;24(1):67-74.

82. Elsous A, Radwan $M$, Al-Sharif $H$, Abu Mustafa A. Medications Adherence and Associated Factors among Patients with Type 2 Diabetes Mellitus in the Gaza Strip, Palestine. Front Endocrinol. 2017 Jun 9;8:100.

83. Ahmad NS, Ramli A, Islahudin F, Paraidathathu T. Medication adherence in patients with type 2 diabetes mellitus treated at primary health clinics in Malaysia. PPA. 2013 Jun;525.

84. Kripalani S, Risser J, Gatti ME, Jacobson TA. Development and Evaluation of the Adherence to Refills and Medications Scale 
(ARMS) among Low-Literacy Patients with Chronic Disease. Value in Health. 2009 Jan;12(1):118-23.

85. Nita Y, Saputra FM, Damayanti S, Pratiwi PI, Zukhairah R, Sulistyarini A, et al. Medication adherence in the elderly with chronic diseases using the Adherence to Refill and Medication Scale (ARMS). In: Zairina E, Khotib J, Ardianto C, Sulaiman SAS, Sands $C D$, Welty TE, editors. Unity in Diversity and the Standardisation of Clinical Pharmacy Services [Internet]. 1st ed. CRC Press; 2017 [cited 2021 Feb 20]. p. 175-8. Available from:

https: / / www.taylorfrancis.com/books/978 1351622981/chapters/10.1201/9781315112 756-30

86. Mayberry LS, Gonzalez JS, Wallston KA, Kripalani S, Osborn CY. The ARMS-D out performs the SDSCA, but both are reliable, valid, and predict glycemic control. Diabetes Research and Clinical Practice. 2013 Nov; 102(2):96-104.

87. Chan EKH, Zumbo BD, editors. Validity and Validation in Social, Behavioral, and Health Sciences. 1st ed. 2014. Cham: Springer International Publishing: Imprint: Springer;
2014. 1 p. (Social Indicators Research Series).

88. Basu S, Garg S, Sharma N, Singh Mm. Improving the assessment of medication adherence: Challenges and considerations with a focus on low-resource settings. Tzu Chi Med J. 2019;31(2):73.

89. Zongo A, Guénette L, Moisan J, Grégoire JP. Predictive Validity of Self-Reported Measures of Adherence to Noninsulin Antidiabetes Medication against Control of Glycated Hemoglobin Levels. Canadian Journal of Diabetes. 2016 Feb;40(1):58-65.

90. Forbes CA, Deshpande S, Sorio-Vilela F, Kutikova L, Duffy S, Gouni-Berthold I, et al. A systematic literature review comparing methods for the measurement of patient persistence and adherence. null. $2018 \mathrm{Sep}$ 2;34(9):1613-25.

91. Anghel LA, Farcas AM, Oprean RN. An overview of the common methods used to measure treatment adherence. Medicine and Pharmacy Reports [Internet]. 2019 Apr 22 [cited 2021 Mar 22]; Available from: https://medpharmareports.com/index.php /mpr/article/view/1201 